\title{
Canine hypoparathyroidism: case report
}

\author{
[Hipoparatireoidismo canino: relato de caso] \\ M.J.L. Cardoso ${ }^{1}$, M. Melussi ${ }^{2}$, F.S. Costa ${ }^{3}$, R. Fagnani ${ }^{1}$, L. Holsback ${ }^{1}$, \\ A. Zacarias Júnior ${ }^{1}$, T.H.C. Patelli ${ }^{1}$ \\ ${ }^{1}$ Universidade Estadual do Norte do Paraná - UENP - Bandeirantes, PR \\ ${ }^{2}$ Espaço Vida Veterinária - Londrina, PR \\ ${ }^{3}$ Universidade Federal Rural de Pernambuco - UFRPE - Recife, PE
}

\begin{abstract}
Primary hypoparathyroidism is an uncommon endocrinopathy in dogs, resulting from absolute or relative deficiency in the secretion of parathormone (PTH). The dog presented signs of hypocalcemia, including muscular spasms, tetany and cramps, evolving to tonic-clonic seizures and fever. Emergency therapy for hypocalcemia included glucose physiological solution at $0.45 \%$ and calcium gluconate administered intravenously. Diagnosis was confirmed by the presence of hypocalcemia, hyperphosphatemia and a decrease in parathormone $(\mathrm{PTH})$.
\end{abstract}

Keywords: dog, parathyroid, hypocalcemia, PTH

\section{RESUMO}

O hipoparatireoidismo primário é uma endocrinopatia incomum em cães, resultante da deficiência absoluta ou relativa na secreção do paratormônio (PTH). O cão apresentava sinais de hipocalcemia, incluindo espasmos musculares, tetania e cãibras que evoluíram para convulsões tônico-clônicas e febre. A terapia de emergência para hipocalcemia incluiu solução glicofisiológica 0,45\% e gluconato de cálcio por intravenosa. $O$ diagnóstico foi confirmado pela presença de hipocalcemia, hiperfosfatemia e diminuição do paratormônio (PTH).

Palavras-chave: paratireoide, hipocalcemia, cão, PTH

\section{INTRODUCTION}

Primary hypoparathyroidism is an uncommon endocrinopathy in dogs, resulting from the absolute or relative deficiency in the secretion of parathormone (Schaer et al., 2001; Feldman and Nelson, 2004; Russel et al., 2006). This deficiency will cause hypocalcemia and hyperphosphatemia due to the loss of PHT action on bones, kidney and intestines. The main signs of hypoparathyroidism are directly related to the decreased concentration of ionized calcium in blood, leading to an increase in neuromuscular activity (Schenk and Chew, 2008). Hypocalcemia signs are similar, regardless of the cause. Once identified, the causes of hypocalcemia must be sought, with the objective

Recebido em 29 de abril de 2013

Aceito em 30 de julho de 2014

E-mail: maurolahm@gmail.com of formulating treatment strategies and prognosis in both short- and long-term (Feldman and Nelson, 2004).

\section{CASE REPORT}

A female dog, 4-years old, not spaded, of the mini Schnauzer breed, with a history of 30-days muscular spasm, tetany and cramps was treated at the Clínica Veterinária Pet Center in the city of Londrina-PR. The symptoms evolved into tonic-clonic convulsions, fever, emesis and intermittent facial pruritus, anxiety, agitation, tachypnea with a 7-day evolution. Upon physical examination, hyperthermia $\left(39.7^{\circ} \mathrm{C}\right)$, tachycardia, physiological arrhythmia, tachypnea, dysmetria, discreet ataxia, tremors and tetany were observed. No alteration was observed in the remaining parameters. 
Initial intravenous therapy was performed with glucose physiological solution at $0.45 \%$, calcium gluconate $(0.5 \mathrm{~mL} / \mathrm{kg}$ IV during 30 minutes $)$ in bolus, dipyrone $(25 \mathrm{mg} / \mathrm{kg}$ IV) and diazepam $(0.3 \mathrm{mg} / \mathrm{kg}$ IV). Approximately thirty minutes after the therapy with calcium, the dog presented discreet fasciculations. Maintenance therapy was initiated only with calcium gluconate, and other drugs were introduced after measuring ionized calcium and PTH levels and consequent confirmation of HPP.

Severe hypocalcemia, hyperphosphatemia, increase in alanine aminotransferase (ALT) and decrease in serum PTH (Table 1) were the alterations seen in laboratory examinations. No alterations could be observed in the complete blood count, urinalysis or abdominal ultrasound scan. T-waves with increased amplitude and duration were the changes observed in electrocardiography (Figure 1). Clinical signs that are compatible with hypocalcemia and the decrease in ionized calcium associated with the decrease in PTH confirmed the HPP diagnosis. The measuring of PTH was performed using the commercial kit IRMA PTH (Immunotech SAS, Marseille, France). For the measurement of ionized calcium, the commercial kit by selective ion technique (Analisador de Íons Seletivo Iselab, Drake SL0014, São José do Rio Preto $\mathrm{SP})$ was used.

Table 1. Laboratory findings for a Dog, Schnauzer, female, 4 years with primary hypoparathyroidism

\begin{tabular}{lcccc}
\hline & Day 1 & Day 7 & Day 30 & Reference \\
\hline Albumin & 28 & 29 & 30 & $26-33 \mathrm{gm} / \mathrm{L}$ \\
Alanine aminotransferase & 17.1 & 20.1 & 20.9 & $4.8-24 \mathrm{U} / \mathrm{L}$ \\
Ionized calcium & 0.49 & 1.4 & 1.19 & $1.15-1.35 \mathrm{mmol} / \mathrm{L}$ \\
Total calcium total & 1.6 & 1.85 & 2.72 & $2.25-2.82 \mathrm{mmol} / \mathrm{L}$ \\
Cholesterol & 2.4 & 3.59 & - & $3.48-6.96 \mathrm{mmol} / \mathrm{L}$ \\
Creatinine & 61.88 & 113.15 & 78,68 & $44.2-132.6 \mu \mathrm{mol} / \mathrm{L}$ \\
Alkaline phosphatase & 42 & 97 & 114 & $20-156 \mathrm{U} / \mathrm{L}$ \\
Phosphorus & 2.23 & 1.65 & 1.32 & $0.84-2.0 \mathrm{mmol} / \mathrm{L}$ \\
Globulin & 37 & 35 & 37 & $27-44 \mathrm{gm} / \mathrm{L}$ \\
Protein total & 65 & 64 & 67 & $54-71 \mathrm{gm} / \mathrm{dL}$ \\
Parathormone & $<0,3$ & 0,586 & $<0,3$ & $1,9-12,38 \mathrm{pmol} / \mathrm{L}$ \\
Urea & 11.78 & 14.64 & 10.26 & $7.64-21.38 \mathrm{mmol} / \mathrm{L}$ \\
\hline
\end{tabular}

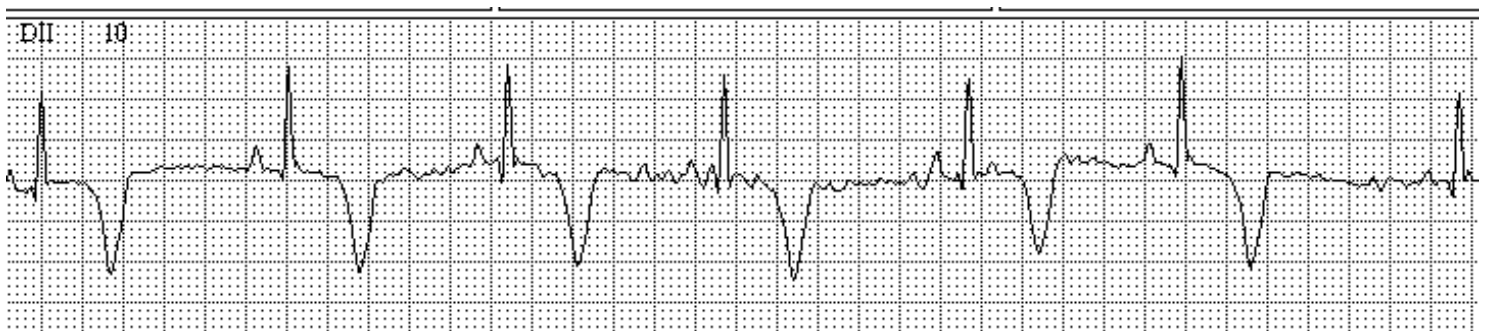

Figure 1. Lead I, II, III, aVR, aVL ECG tracing from a dog indicating T waves with increased amplitude and duration. $50 \mathrm{~mm} / \mathrm{sec}$.

Calcitrol (20ng/kg/day during 10 days, then $10 \mathrm{ng} / \mathrm{kg} / \mathrm{day})$ and calcium carbonate administered orally (1g/day and after 30 days $0.5 \mathrm{~g} /$ day) were used as maintenance treatment. After a 4-month treatment, the dog presented recurrence of mild hypocalcemia after the reduction of calcium gluconate supplementation and pseudocyesis, and needed emergency treatment again. The maintenance treatment was continued for two months. Ovariosalpingohisterectomy was also recommended. After 2 years since the diagnosis and initial treatment, and 6 months since the total removal of calcium, no new signs were observed regarding hypocalcemia. 


\section{DISCUSSION}

Hypoparathyroidism has been described in dogs in association to the atrophy or severe destruction of parathyroid due to lymphocytic parathyroiditis, enteropathy by protein loss, after laryngectomy, thyroidectomy and/or chemotherapy (Kimmel et al., 2000; Mellanby et al., 2005). In the case described, it was not possible to identify the cause of the disease, since no histopathological examination was performed. However, the disease is probably due to lymphocytic thyroiditis. Hypoalbuminemia was not present, discarding, therefore, the hypothesis of pseudohypocalcaemia by hypoproteinemia or hypoparathyroidism secondary to enteropathy by protein loss. Puerperal tetany, acute kidney injury (AKI) or toxicity by ethylene glycol were excluded as causes of hypocalcemia based on history or absence of clinical evidence for azotemia, lactation or exposure to ethylene glycol.

The animal reported here was a 4 year old female mini Schnauzer - findings which were similar to the ones found in literature, where animals with hypoparathyroidism present ages between 6 months and 13 years of age, with average age of 4.8 years, being $60 \%$ female (Feldman and Nelson, 2004, Russel et al., 2006). Regarding breed, Bassett (1998) and Feldman and Nelson (2004) reported higher incidence in German Sheppard and mini Schnauzer dogs. Recently, a case of hypoparathyroidism in a Schnauzer was described in South Korea (Kang and Park, 2009).

The clinical signs presented were muscular spasms on hind limbs, fever, sporadic emesis, anxiety, agitation, paroxysmal episodes of tonicity in limbs, choking, dysmetria in hind limbs, claudication of right hind limb, tremors and discreet ataxia. These signs are frequently observed in hypoparathyroidism, except for sporadic emesis and choking. Among the signs considered uncommon, the dog presented seizures, hyperventilation, facial pruritus (hyperesthesia) and lethargy (Feldman and Nelson 2004; Schenck and Chew, 2008).

Hypocalcemia, discrete hyperphosphatemia and decrease in intact PTH serum levels were the laboratory alterations found. In hypoparathyroidism, a decrease in serum concentration of calcium, an increase in serum concentration of phosphorus, a normal kidney function test and an absolute or relative decrease in serum PTH are commonly found results. In several cases the dogs presented a decrease in vitamin D (Refsal et al., 2001; Feldman and Nelson, 2004), but in this case, vitamin D levels were not measured.

In order to obtain the diagnosis of primary hypoparathyroidism, it is necessary to measure the level of ionized calcium. The measuring of ionized calcium must be performed exclusively with heparinized total blood or plasma samples for describes (Holowaychuk et al., 2009). The measuring of intact PTH was validated in both dogs and cats, and it is extremely useful in the diagnosis of primary hypoparathyroidism, as well as for discarding other causes of hypocalcemia (Barber et al., 1993; Gear et al., 2005). In primary hypoparathyroidism, PTH can be decreased, subnormal or normal (Feldman and Nelson, 2004; Russel et al., 2006; Kang and Park, 2009).

Electrocardiography (ECG) might contribute in the diagnosis of hypocalcemia, since there is an extension in the duration of the action potential of cardiac cells resulting in an increase in the duration of ST and QT segment. Positive correlation can be observed between the severity of hypocalcemia and the duration of the ST segment. The electrocardiographic findings that are common in hypocalcemia are: broad and deep $\mathrm{T}$ wave, extension of QT interval and bradycardia. However, there is no association between these signs and cardiovascular findings in physical examination such as arrhythmias, weak pulse or muffling of cardiac sounds (Feldman and Nelson 2004; Russel et al., 2006). In the electrocardiographic examination in this report, $\mathrm{T}$ waves with increased amplitude and duration were observed, findings which were compatible with electrolytic alterations.

The purpose of treatment in primary hypoparathyroidism is to increase serum calcium levels. The recommended emergency therapy is $0.5-1.5 \mathrm{~mL} / \mathrm{kg}$ or $5-15 \mathrm{mg} / \mathrm{kg}$ slowly during 10 to 30 minutes, and in some cases, there is the need of repeated doses of calcium until the stabilization of the animal (Russel et al., 2006). The intravenous infusion of calcium gluconate at $10 \%$ at the dose of $0.5 \mathrm{~mL} / \mathrm{kg}$ during 30 minutes 
was the treatment adopted for controlling hypocalcemic tetany, without the need of repeating the dose. With the persistence of hypocalcemy and hyperphosphatemia after initial therapy, in the absence of clinical signs, oral maintenance therapy was prescribed using calcitriol and calcium gluconate.

In most cases, primary hypoparathyroidism maintenance therapy onsisting of oral administration of vitamin $\mathrm{D}$ and calcium permanently. In many cases, calcium supplementation is started and interrupted, since in most cases, dietary calcium is enough for the maintenance of the needs of the animal. The oral supplementation of vitamin D promotes both the absorption of intestinal calcium and reabsorption of renal calcium, decreasing the need for oral supplementation. The most commonly used is calcitriol (1.25 dihydroxyvitamin $\mathrm{D}_{3}$ ) at the dosage of $20-40 \mathrm{ng} / \mathrm{kg} /$ day during 3 to 5 days, and after at 10-20ng/kg (Refsal et al., 2001; Schaer et al., 2001; Feldman and Nelson, 2004; Russel et al., 2006), as in the case described.

Calcium oral supplementation can be achieved with the intake of calcium gluconate, calcium lactate, calcium chloride and calcium carbonate, each of them presenting both advantages and disadvantages. Calcium carbonate is the formulation of choice for oral calcium supplementation in dogs and cats. Dosage in dogs is 1 to $4 \mathrm{~g} /$ day and in cats 0.5 to $1 \mathrm{~g} /$ day. These dosages are approximate, and the replacement of vitamin D is the primary therapy to stabilize calcium levels. The reduction of calcium was performed after 6 months of therapy with no recurrence to date, up to two to four months is recommended when vitamin D supplementation and calcium levels in diet are ideal (Refsal et al., 2001; Schaer et al., 2001; Feldman and Nelson 2004; Russel et al., 2006).

Hypercalcemia is the most common complication in vitamin $\mathrm{D}$ and calcium supplementation in dogs with hypoparathyroidism (Basset, 1998; Feldman and Nelson, 2004; Ulutas et al., 2006). However, during the treatment of this female dog this was not observed.

Pseudocyesis associated to galactorrhoea was probably responsible for recurrent hypocalcemia, since breastfeeding is the most common cause of hypocalcemia in dogs. This recurrence could probably have been avoided if the female dog had been neutered.

According to this case report, it can be concluded that emergency treatment for primary hypoparathyroidism including calcium gluconate is fundamental since it corrects the consequences of low PTH concentration such as hypocalcemia and hyperphosphatemia. The diagnosis can be defined by means of excluding other causes of hypocalcemia, correlated to compatible clinical signs and laboratory results.

\section{REFERENCES}

BARBER, P.J., ELLIOT, J., TORRANCE, A.G. Measurement of feline intact parthyroid hormone: assay validation and sample handling studies. J. Small Animal Pract., v.34, p.614-620, 1993.

BASSETT, J.R. Hypocalcemia and hyperphosphatemia due to primary hypoparathyroidism in a six-month-old kitten. $J$. Am. Anim. Hosp. Assoc., v.43, p.503-507, 1998.

FELDMAN, E.C.; NELSON, R.W. Hypocalcemia and primary hypoparathyroidism. In: FELDMAN, E.C.; NELSON, R.W. (Eds.) Canine and Feline Endocrinology and Reproduction, 3. ed., St Louis: WB Saunders 2004. p.716-742.

GEAR R.N., NEIGER, R., SKELLY, B.J., et al. Primary hyperparathyroidism in 29 dogs: diagnosis, treatment, outcome and associated renal failure. J. Small Anim. Pract., n.46, p.10$16,2005$.

HOLOWAYCHUK, M.K.; HANSEN, B.D.; DEFRANCESCO, T.C. et al. Ionized hypocalcemia in critically III dogs. J. Vet. Intern. Med., v.23, p.509-513, 2009.

KANG, M.H.; PARK, H.M. Primary hypoparathyroidism in a miniature Schnauzer dog. J. Vet. Clin., v.26, p.603-605, 2009.

KIMMEL, S.E.; WADDELL, L.S.; MICHEL, K.E. Hypomagnesemia and hypocalcemia associated with Protein-losing enteropathy in Yorkshire Terriers: Five cases (1992-1998). J. Am. Vet. Med. Assoc., v.217, p.703-706, 2000. 
MELLANBY, R.J.; MELLOR, P.J.; ROULOIS, A. et al. Hypocalcaemia associated with low serum vitamin $\mathrm{D}$ metabolite concentrations in two dogs with protein-losing enteropathies. $J$. Small Anim. Pract., v.46, p.345-351, 2005.

REFSAL, K.R.; PROVENCHER-BOLLOGER, A.L.; GRAHAM, P.A. et al. Update on the diagnosis and treatment of disorders of calcium regulation. Vet. Clin. North Am. Small Anim. Pract., v.31, p.1043-1062, 2001.

RUSSEL, N.J.; BOND, K.A.; ROBERTSON, I.D. et al. Primary hypoparathyroidism in dogs: a retrospective study of 17 cases. Austr. Vet. J., v.84, p.285-290, 2006.
SCHAER, M.; GINN, P.E.; FOX, L.E. et al. Severe calcinosis cutis associated with treatment of hypoparathyroidism in a dog. J. Am. Anim. Hosp. Assoc., v.37, p.364-369, 2001.

SCHENCK, P.A.; CHEW, D.J. Hypocalcemia: a quick reference. Vet. Clin. North Am. Small Anim. Pract., v.38, p.455-458, 2008.

ULUTAS, B.; VOYVODA, H.; PASA, S. et al. Clodronate treatment of vitamin D-induced hipercalcemia in dogs. J. Vet. Emerg. Crit.Care, v.16, p.141-145, 2006. 